\title{
Business Development Strategy for Muslimah Female UMKM Person of Songket Fabric in Batu Bara Using the Triple Helix Method
}

\author{
Muhammad Arif ${ }^{1}$, Yenni Samri Juliati Nst' ${ }^{2}$, Muhammad Alqodri Pratama ${ }^{3}$ \\ ${ }^{1,2}$ Universitas Islam Negeri Sumatera Utara, Indonesia \\ ${ }^{3}$ Postgraduate Program in Universitas Islam Negeri Sumatera Utara, Indonesia \\ yenni.samri@uinsu.ac.id,Mhdalqodripratama05@gmail.com
}

\begin{abstract}
This study aims to determine how the strategies used by Muslim women who do UMKM songket Batubara in developing their businesses. The sample used in this study were four MSME actors of songket Batubara, and the approach used was an inductive qualitative approach. In this study, the data analysis tools used were SWOT analysis (Strength, Weakness, Opportunities, and Threats). The results of the analysis show that this study produces a triple helix stakeholder model in this study as: a. Academics in this case are a source of knowledge with the latest theories and are relevant to the business developed by Batu Bara songket business actors run by Muslim women in Batu Bara to gain a competitive and sustainable advantage. $b$. Business is an entity that carries out business processes in creating added value and maintaining sustainable growth. c. The government acts as a regulator as well as a controller that has regulations and responsibilities in developing businesses. The government also has a role to coordinate stakeholders who contribute to the development of women's businesses in the treatment of Batu Bara songket cloth. Based on the results of the SWOT analysis, it can be seen that the Stakeholders are implementing the SO (Strength and Opportunities) strategy, which is a strategy in which the company uses the strengths and opportunities it has to run its business.
\end{abstract}

Keywords

business development; UMMkain songket Batubara; triple helix

\section{Introduction}

Small Business is a productive economic business that stands alone, carried out by individuals or business entities that are not subsidiaries, large businesses with total net assets or annual sales proceeds as regulated in this Law. Micro, Small and Medium Enterprises (MSMEs) should be recognized as a strategic force in accelerating regional development, because the growth of Micro, Small and Medium Enterprises (MSMEs) has increased every year, while the number of Micro, Small and Medium Enterprises (MSMEs) in Indonesia in 2018 as many as 64.19 million people, while Indonesia's population in 2018 is predicted to be 265 million people. And proven to contribute 56.53\% to GDP (Gross Domestic Product) and $97.30 \%$ to employment.

A strategic approach is needed to develop MSMEs by involving the participation of various parties for the realization of the progress of MSMEs. In developing MSMEs, cooperation between relevant stakeholders is needed, the Triple Helix model with the ABG formula which stands for Academy, Business, and Government is suitable for use as a model of cooperation. The UMKM development program deals with various sectors in the business processes that are carried out, so it requires the roles of various stakeholders. The success of 
the Kain Songket UMKM development program in Batu Bara depends on how the stakeholders run the program according to their main duties and functions. The development of MSMEs also depends on how the government can collaborate with various stakeholders for the realization of MSMEs in the future (Suryana, 2009).

The number of Small and Medium Enterprises (MSMEs) in Indonesia described above, women as MSME actors have a significant number. The participation of women in the business sector from time to time continues to increase. If in 2012 the involvement of women in the entrepreneurial sector was 58 percent. Data from Bank Indonesia states, the total number of micro, small and medium enterprises (MSMEs) in 2018 reached 57.83 million, with more than $60 \%$ managed by women (the number of female MSME players in Indonesia reached 37 million).

Its development and growth have caught the attention of researchers. The research, among others, concerns the profile of women businessmen, whether there are differences between business women and men entrepreneurs in terms of motivation, challenges and obstacles in doing business. In addition, research on the profile of rural women businessmen engaged in the home-industry sector focuses on demographic and motivation aspects. This study also aims to determine the attitudes of families and society towards women businessmen, as well as to understand the problems faced by women businessmen.

The development of MSME coal songket cloth located in the Village of Padang Genting, Kec. Talawi Kab. Coal is doing quite well. However, there are still several inhibiting factors in the development of songket SMEs in Batu Bara, in the results of interviews with business actors it is explained that the things that are still obstacles are the low quality of human resources, limited access to marketing, and limited capital. The limited quality of human resources, this is because existing human resources are relatively difficult to adopt new technological developments. One of the ways of marketing MSMEs in Batu Bara is by participating in exhibitions, holding product bazaars and others which are facilities for the parties cooperating in the program.

However, this is not optimal because the exhibition only represents a number of existing songket business actors. For factors caused by limited capital, the problem faced by songket cloth MSMEs is financial difficulties to develop and expand a business, although in fact access and capital assistance through the Industry, Cooperatives and MSMEs Office of Batu Bara Regency has been provided through loans from the Multi-Purpose Cooperative KSU Batubara.

There are three stakeholders in developing the Batu Bara songket cloth UMKM. The collaboration between the three stakeholders is referred to as the Triple Helix, namely academics, business, and government. The purpose of this research is to find out the strategies used by Muslim women entrepreneurs who do umkm songket Batubara, what strategies they use for their business development, and how the roles of stakeholders in developing the Batubara songket cloth business.

\section{Review of Literatures}

\subsection{Business Development Strategy a. Definition of Strategy}

In the language of strategy comes from the word strategic which means according to a strategy or plan and strategy which means strategy science. According to the term strategy is a careful plan of activities to achieve specific goals. Strategy is how to move troops to the most advantageous position before actual combat with the enemy (M. Suyanto, 2007) the 
bank (Audi, M. F, et al, 2016). Syamsul Hadi, the easier a system is to learn and use, it will increase customer interest in using mobile banking (Syamsul Hadi, 2015).

Strategy has a certain hierarchy. The first is the corporate level strategy. Corporate strategy, describes the direction of growth and management of various business fields in an organization to achieve a balance of products and services produced. The second is the business unit level strategy. This strategy usually emphasizes efforts to increase organizational competitiveness in one industry or one functional level. Strategy at this level creates a framework for functional management such as production and operations, finance, human resources (HR), marketing, and research and innovation (Research and innovation) (Diah, 2004). Marketing strategy is a plan that outlines the company's expectations of the impact of various marketing activities or programs on the demand for products or product lines in certain target markets" (Sitepu, 2020). "Marketing strategy is a plan that outlines the company's expectations of the impact of various marketing activities or programs on the demand for products or product lines in certain target markets (Chandra in Dianto, 2020).

\section{b. Definition of Development}

With regard to business development, this depends on the ability of entrepreneurs and managers in their daily business. According to the Big Indonesian Dictionary (KBBI), development is a process, a method, an act of developing. Development is a planned effort by the organization to increase the knowledge, skills and abilities of employees. Development is more focused on increasing knowledge to do work in the future, which is carried out through an integrated approach with other activities to change work behavior (Marihot, 2002).

\section{c. Business Development Strategy in Islamic Perspective}

Islam requires every Muslim, especially those with dependents to work. Work is one of the main reasons that allows humans to have property. As quoted by Mardani "Sharia Business Law" according to Dr. Yusuf Qardhawi, work is part of worship and jihad, if the worker is consistent with Allah's rules, his intention is pure and does not forget Him. by working, humans can carry out the duties of the caliphate, protect themselves from immorality, and achieve very large goals. In the interpretation of the Quraish Shihab it is explained about the verse that "each Muslim and Kafir, will get a position in accordance with what he does. It is all so that Allah will show His justice to them and fulfill the rewards of their deeds, without being cheated at all, because they are entitled to receive the reward that has been determined for him (M. Quraish, 2002).

\subsection{Women and the Economy}

\section{a. Women's Involvement in the Economy}

Siti Khadijah, wife of the Prophet Muhammad, grew up in the midst of a respected family and walled in wealth, not making Siti Khadijah an arrogant figure, instead her features made her humble. The nickname At-Thairah inspired him to appreciate that Siti Khadijah was a figure who was able to maintain her chastity. In 575 AD, Siti Khadijah's mother passed away. 10 years later, his father passed away. Being an orphan along with an abundance of inheritance for some humans can make themselves complacent and wasteful.

However, this is not the case with Siti Khadijah. The death of her parents has made her grow up to be an independent woman. Siti Khadijah continues her family tradition as a trader. Siti Khadijah's cold hands made her family's business flourish (Muslich, 2008). In his preaching the Prophet also gave instructions about trading or buying and selling to a woman named Qilat Ummi Bani Ammar regarding price placement. The Prophet advised him: If you want to buy or sell something, then set the price you want to buy or sell it. Either you give it or not. 


\section{b. Islamic Views of Working Women}

Islam does not prohibit women from working. Moreover, the conditions are urgent, as long as they do not forget their main task of taking care of the household, children, and serving their husbands well. Even Islam does not prohibit women from leading, like Queen Balqis who managed to lead her country. This is proof that women can lead. Islam allows women to lead outside the home, but not inside the household. Men are leaders for their wives and families without exception (Barbara, 2001).

\section{c. Differences in Entrepreneurship Between Men and Women}

The profile of a woman entrepreneur is similar to that of a male entrepreneur. For example, the age structure is similar to a mean age of 41 years. However, the proportion of young entrepreneurs is slightly higher among women than men (figure 2.1). Also education levels are very similar and generally high for both sexes (International Finance Corporation (IFC), 2016).

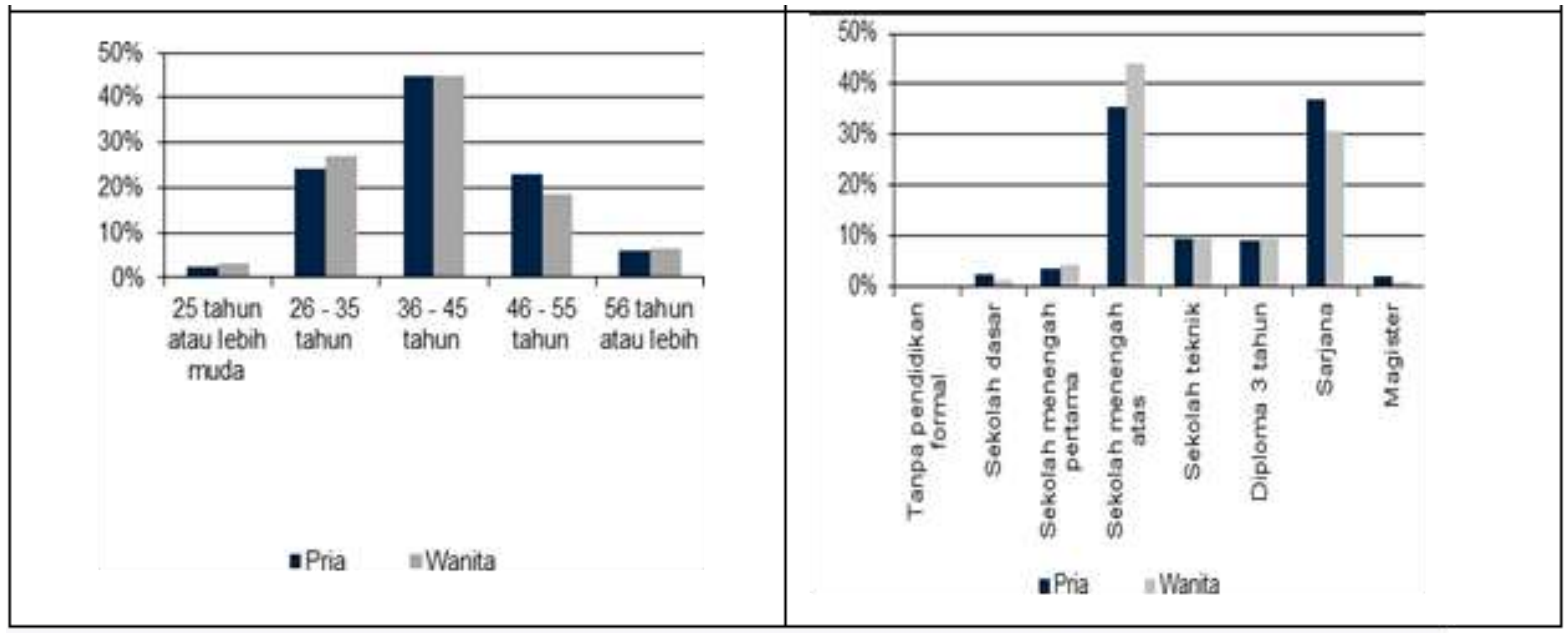

Figure 1. Age of Enterpreneur per Gender Figure 2. Enterpreneur Education per Gender

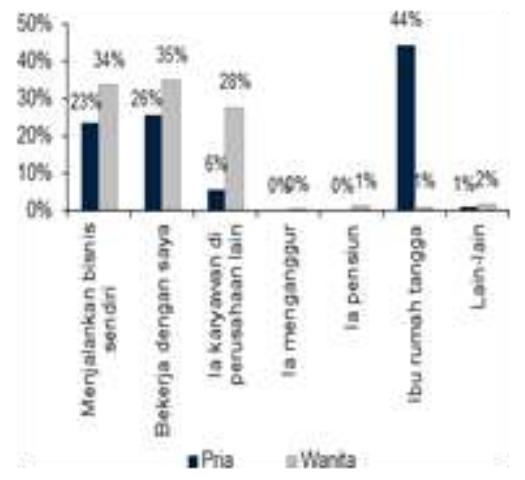

Figure 3. Spouse's Occupation

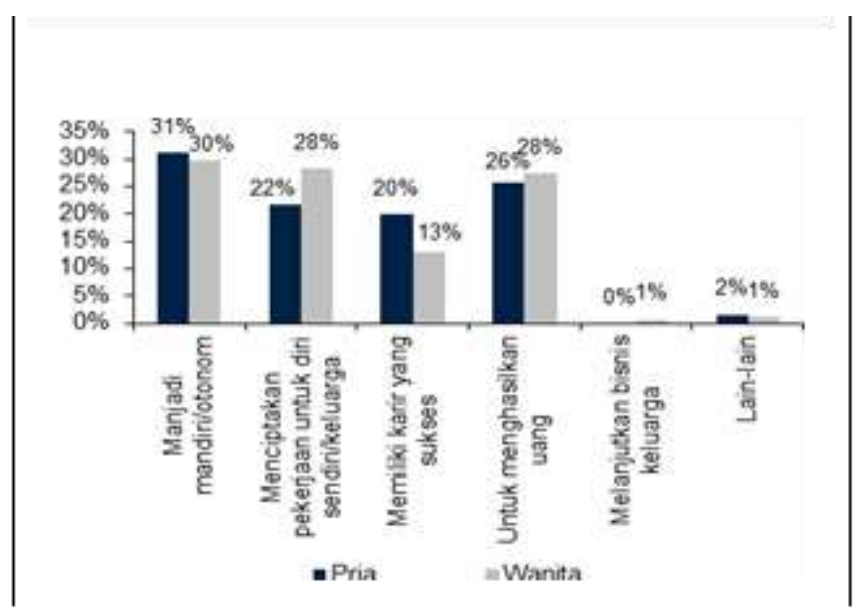

Figure 4. Motivation to become an entrepreneur

\section{d. Difficulties for Women in Starting a Business}

Almost all companies (77\%) were founded by entrepreneurs; $19 \%$ of the businesses are inherited and in only 3\% of the cases the man or woman is the shareholder of the spouse's business. Therefore, most entrepreneurs face challenges in getting financing to grow their business. 


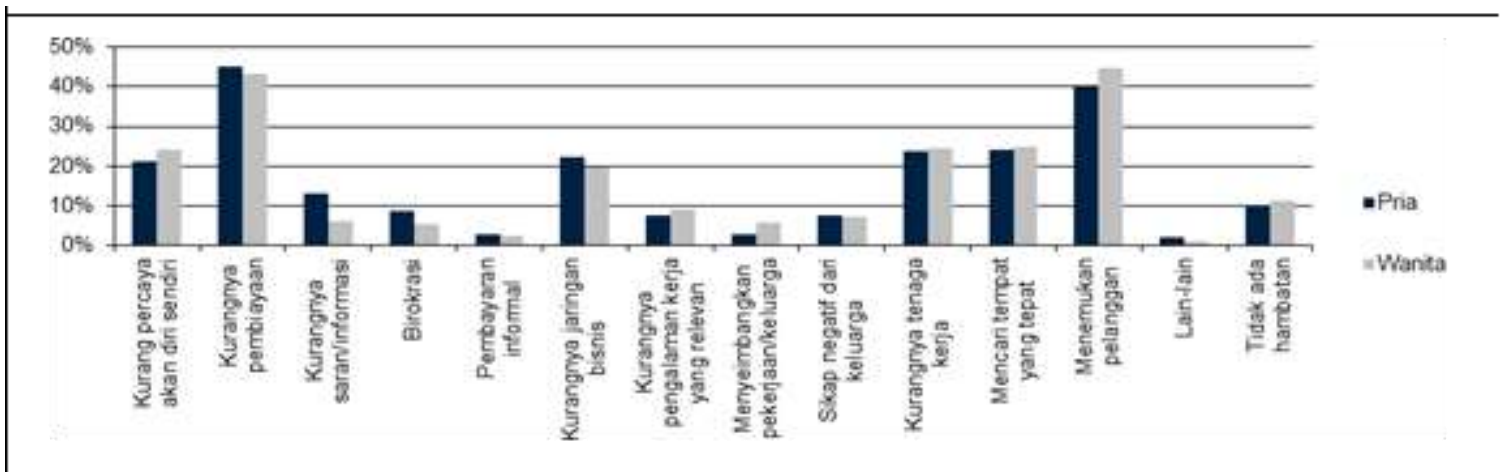

Figure 5. Main Challenges in Starting a Business per Gender

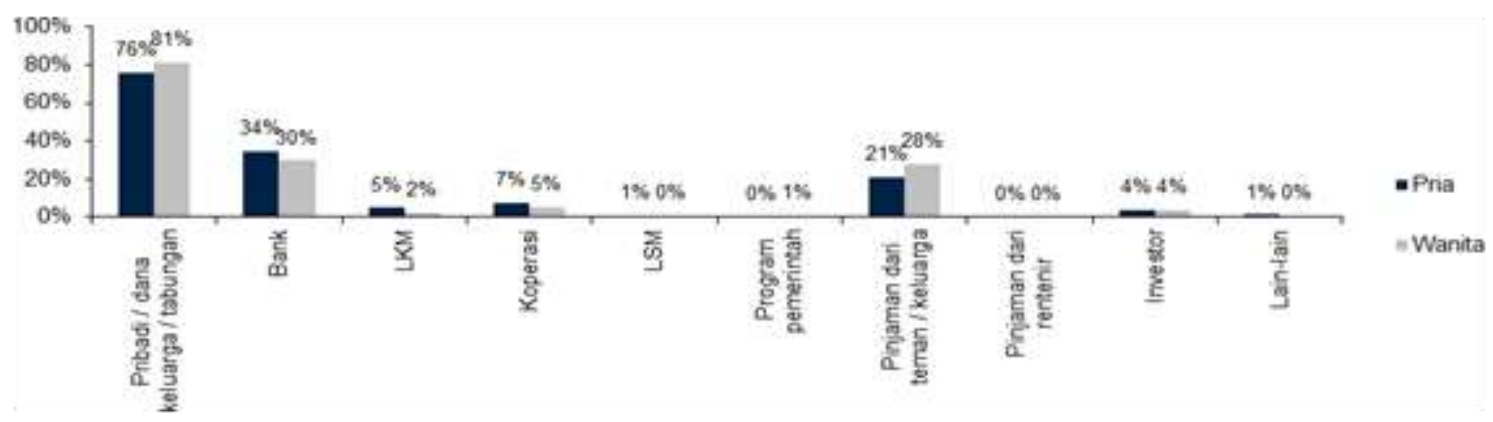

Figure 6. Sources of Financing during Business Start-up Period per Gender

Overall women face the same challenges as men in running a business (figure 7). Most of the challenges are related to competition as well as costs of doing business, leasing and the problems of finding and retaining quality employees.

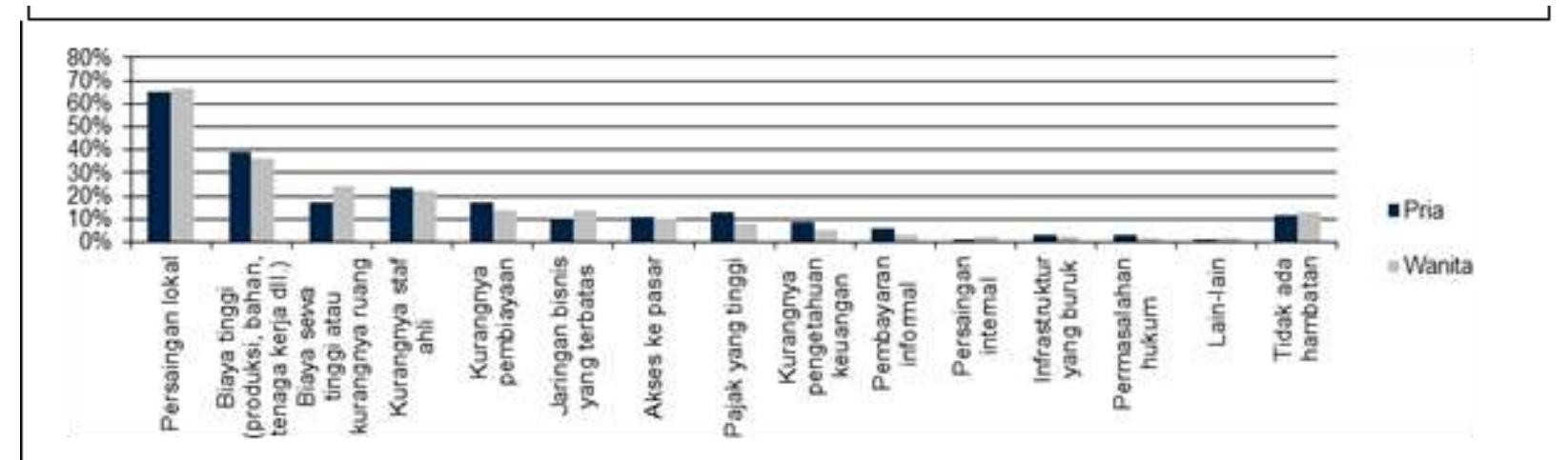

Figure 7. Main Constraints to Running a Business per Gender

\subsection{Micro, Small and Medium Enterprises}

a. Definition of Business

Business is to carry out activities permanently and continuously with the aim of obtaining profit, whether organized by individuals or business entities in the form of legal entities or not in the form of legal entities, which are established and domiciled in a region within a State. The definition of small business is clearly stated in Law No.9 of 1995, which states that a small business is a business with a net worth of at most Rp. 200,000,000 not 
including land and buildings for business premises. With the result of net sales per year of not more than IDR 1,000,000,000 (M. Tohar, 2000).

Tabel 1. Defenisi UMKM di Indonesia

\begin{tabular}{|c|c|}
\hline & $\begin{array}{c}\text { Assets (Excluding Land and } \\
\text { Buildings) }\end{array}$ \\
\hline Micro & $<$ Rp 50 million \\
\hline Small & $\mathrm{Rp} 50-500$ million \\
\hline Intermediate & $\mathrm{Rp} 500$ million -10 billion \\
\hline Corporation & $>\mathrm{Rp} 10$ billion \\
\hline
\end{tabular}

Source: UU UKM 20/2008, Ministry of Cooperatives and UKM

\subsection{Songket Cloth}

Songket woven cloth is a type of traditional Malay and Minangkabau woven fabric in Indonesia, Malaysia and Brunei. Songket is classified in the brocade weaving family. Batu Bara songket cloth has its own characteristics, this can be seen from the process of making songket cloth still using wood looms in the traditional way, but still of good quality.

Songket Batu Bara has various types of colors such as pink, sea green, yellow, heart red, beige, pink and other interesting color combinations. These Batu Bara songket fabrics are produced by skilled and talented weavers. They weave with the best choices of threads, such as polyester and silk threads, which are the gold and silver thread motifs that give the songket a sparkling impression, so that the songket produced is of good quality. The advantages of this songket are light and don't fade so they are more comfortable to wear.

\subsection{Triple Helix}

The Triple Helix concept is an interaction between universities, business and government developed in the 1990s by Etzkowitz \& Leydesdorff. This concept is often used as a normative framework among researchers for understanding the interactions between key actors in a system's innovation. In addition, it is also a general strategy used by the government in developing policy innovation. One of the main claims of the Triple Helix thesis is that between academia, industry and government provide optimal conditions for innovation (Muhammad, 2018).

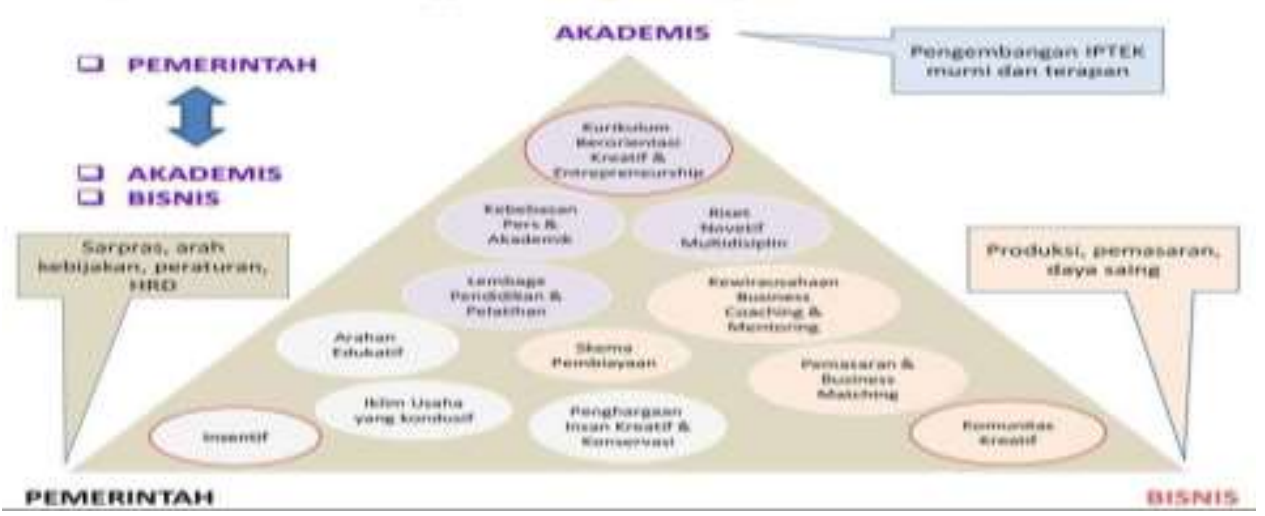

Figure 8. Triple Helix: Actors Driving Creative / Innovative Economy Development 


\section{Research Methods}

The type of research that will be used in this research is to use qualitative methods that are inductive analysis, namely by collecting, compiling and describing various actual documents, data and information. The material obtained will be interpreted in the form of exposure and analysis so that the objectives of this research can be achieved.

This research was conducted in Batubara Regency for academics to be conducted at the Tarbiyah Batubara College of Science (STIT BB), MSME actors in Songket cloth in Batu Bara Regency, such as Buk Nurlaila, the owner of Sa'amah songket cloth, Buk Aisyah, the owner of Aisyah's songket cloth, Buk Aja Ratna the owner of the songket cloth Yusra and Buk Maysarah the owner of the Maysarah songket. Then for the government, it was carried out at the Cooperatives and UMKM Office in Batu Bara Regency.

The data analysis method that the researcher uses in analyzing the data is descriptive qualitative in which the data is presented in written form and then the analysis is carried out. In this study, the data analysis tools used were SWOT analysis (Strength, Weakness, Opportunities, and Threats).

\section{Discussion}

\subsection{Muslim Women's Business Development, Micro, Small and Medium, Kain Songket Batubara \\ a. Changes in the Economy of Coal Songket Weaving Entrepreneurs}

The socio-economic changes caused by the coal songket weaving activity have had an impact on the songket weaving business actors for a long time, since the weaving activities began. This activity is still a part-time activity for Muslim women until in 1990 it has become a source of livelihood for craftsmen in the Batubara songket woven fabric business.

On the eve of Eid al-Fitr and Eid al-Adha, weavers have prepared everything related to the production process, such as increasing the number of laborers working in weaving, increasing capital, purchasing raw materials for production, for example large quantities of yarn. This means that the meeting business actors are very busy in order to increase and fulfill the demand for woven coal songket from cloth traders.

Songket weavers who have large capital at the time of increasing songket production will feel this change with a change in daily life as seen in the continued increase in weaving production, craftsmen can meet all their needs in large quantities as well. They can fulfill the haj pilgrimage, purchase home furniture, tuition fees, and other economic needs. In addition, entrepreneurs can also invest and increase labor in the business they manage and improve the quality of the songket cloth they manage.

\section{b. The Role of Stakeholders in the Triple Helix Method}

Academics in the Triple Helix method act as a drafter. Such as standardlizing processes and product standardlizing processes and product standardization and human resource skills. Academics in this case are a source of knowledge with the latest theories and are relevant to the business developed by Batu Bara songket business actors run by Muslim women in Batu Bara to gain a competitive and sustainable advantage. So that the role of academics here is to provide information to business actors in Batu Bara songket cloth. In the micro, small and medium enterprise development program that has a role as academics. The following is a collaboration or collaboration on the role of academics with Muslim women entrepreneurs in Batu Bara songket cloth. 
Business is an entity that carries out business processes in creating added value and maintaining sustainable growth. Business in the triple helix method acts as an enable that supports changes in human resources and the resulting product processes.

Muslim women, who practice songket cloth umkm specifically in the Batu Bara area, are about four songket business actors who have been running quite well, and have a good strategy in developing their business. This can be seen from the results of the interviews which said that they had improved the quality of the product that was better, with the addition of better songket woven motifs. The motifs developed include: shoots of bamboo shoots, caul shoots, batikam shoots, pandanus shoots, chain gumball (full motif), randadu flowers, roses, jasmine flowers, sow flowers, mangosteen looks, cempaka sprinkles, and Gigiu.

The government in this triple helix model acts as a regulator. The government acts as a regulator as well as a controller that has regulations and responsibilities in developing businesses. The government also has a role to coordinate stakeholders who contribute to the development of women's businesses in the treatment of Batu Bara songket Batubara.

The Government of Batu Bara Regency through the Office of Cooperatives and MSMEs in developing a songket cloth business to assist or facilitate licensing, conducts exhibitions to introduce Batu Bara songket cloth, conducts trainings in order to improve the quality of its products. In addition to providing assistance with product types, the government of Batu Bara Regency through the Department of Cooperatives and Small and Medium Enterprises (UKM), the government also helps provide business capital assistance that can be used by umkm songket players. The government also provides assistance in wages of a package of tools for making songket cloth, which is given to songket business actors, each of which is given one package.

\subsection{SWOT Analysis Results}

a. Recapitulation of Internal Strength Factors

Following are the results of the recapitulation of internal stakeholder factors, namely the strength factor:

Table 2. Recapitulation of Internal Strength Factors

\begin{tabular}{|l|l|}
\hline No. & Internal Strength Factor \\
\hline $\mathbf{1}$ & $\begin{array}{l}\text { The product quality is maintained and good } \\
\text { More and more Batu Bara songket motifs are being } \\
\text { made } \\
\text { A comfortable working environment enhances the } \\
\text { performance ofcraftsmen }\end{array}$ \\
\hline
\end{tabular}

\section{b. Recapitulation of Internal Weakness Factors}

Following are the results of the recapitulation of the internal stakeholder weakness factors:

Table 3. Recapitulation of Internal Weakness Factors

\begin{tabular}{|c|l|}
\hline No. & Weakness Factor \\
\hline $\mathbf{1}$ & $\begin{array}{l}\text { Lack of capital in running a business } \\
\text { The process of making songket cloth which requires a } \\
\text { long time } \\
\text { Muslim women businesses that do songket cloths still } \\
\text { have limited knowledge about the internet and online } \\
\text { marketing }\end{array}$ \\
\hline
\end{tabular}


Table 4. Recapitulation of External Opportunity Factors

\begin{tabular}{|c|l|}
\hline No. & \multicolumn{1}{c|}{ Opportunity Factor } \\
\hline $\mathbf{1}$ & $\begin{array}{l}\text { There is government attention to the Batu Bara songket } \\
\text { woven cloth } \\
\text { There are regular customers of Batu Bara songket cloth } \\
\text { The high public interest in Batu Bara songket cloth }\end{array}$ \\
\hline
\end{tabular}

Table 5. Recapitulation of Internal Threat Factors

\begin{tabular}{|c|c|}
\hline No. & Threat Factor \\
\hline $\begin{array}{l}\mathbf{1} \\
\mathbf{2} \\
\mathbf{3}\end{array}$ & $\begin{array}{l}\text { The more expensive the raw materials } \\
\text { Availability of human resources } \\
\text { Lack of time management in the process of making songket } \\
\text { cloth }\end{array}$ \\
\hline
\end{tabular}

1. Matrix IFAS (Internal Factor Analysis Summary)

In this IFAS matrix, the data obtained are data derived from the normalization tablefor internal factor weights, Academics, Business and Government.

Table 6. Internal IFAS Matrix

\begin{tabular}{|c|c|c|c|c|}
\hline No. & Internal factors & B & $\mathbf{S}$ & B*S \\
\hline $\mathrm{S}_{1}$ & Product quality is strictly maintained & 0,1465 & 4 & 0,586149 \\
\hline $\mathrm{S}_{2}$ & $\begin{array}{l}\text { More and more Batu Bara songket motifs are } \\
\text { being made }\end{array}$ & 0,1591 & 4 & 0,636222 \\
\hline $\mathrm{S}_{3}$ & $\begin{array}{l}\text { A comfortable working environment enhances } \\
\text { the performance of craftsmen }\end{array}$ & 0,1991 & 3 & 0,597440 \\
\hline $\mathrm{W}_{1}$ & Lack of capital in running a business & 0,1850 & 3 & 0,554968 \\
\hline $\mathrm{W}_{2}$ & $\begin{array}{l}\text { The process of making songket cloth which } \\
\text { requires a long time }\end{array}$ & 0,1457 & 3 & 0,437248 \\
\hline $\mathrm{W}_{3}$ & $\begin{array}{l}\text { Limited place for marketing songket cloth } \\
\text { Batubara }\end{array}$ & 0,1645 & 3 & 0,493565 \\
\hline & Total & 1.00 & & 3,305593 \\
\hline
\end{tabular}


Table 7. Ranking of Strategy Urgency

\begin{tabular}{|c|l|c|}
\hline No. & Internal Factors (sorted by value) & $\mathbf{B} * \mathbf{S}$ \\
\hline $\mathrm{S}_{2}$ & $\begin{array}{l}\text { More and more Batu Bara songket motifs are } \\
\text { being made }\end{array}$ & 0,636222 \\
\hline $\mathrm{S}_{3}$ & $\begin{array}{l}\text { A comfortable working environment enhances } \\
\text { the performance of craftsmen }\end{array}$ & 0,597440 \\
\hline $\mathrm{S}_{1}$ & Product quality is strictly maintained & 0,586149 \\
\hline $\mathrm{W}_{1}$ & Lack of capital in running a business & 0,554968 \\
\hline $\mathrm{W}_{3}$ & $\begin{array}{l}\text { Limited place for marketing Batubara songket } \\
\text { cloth }\end{array}$ & 0,493565 \\
\hline $\mathrm{W}_{2}$ & $\begin{array}{l}\text { The process of making songket cloth which } \\
\text { requires a long time }\end{array}$ & 0,437248 \\
\hline & \multicolumn{1}{|c|}{ Total } & $\mathbf{3 , 3 0 5 5 9 3}$ \\
\hline
\end{tabular}

2. Matrix EFAS (External Factor Analysis Summary)

In this EFAS matrix, the data obtained is data derived from the normalization table for the external factor weights of Academics, Business and Government and also data obtained from the external factor assessment questionnaire.

Table 8. Matrik EFAS

\begin{tabular}{|c|l|c|c|c|}
\hline No. & External Factors & $\mathbf{B}$ & $\mathbf{S}$ & $\mathbf{B} * \mathbf{S}$ \\
\hline $\mathrm{O}_{1}$ & $\begin{array}{l}\text { There is government attention to the Batu Bara } \\
\text { songket woven cloth }\end{array}$ & 0,3257 & 4 & 1,302947 \\
\hline $\mathrm{O}_{2}$ & $\begin{array}{l}\text { There are regular customers of Batu Bara songket } \\
\text { cloth }\end{array}$ & 0,1704 & 3 & 0,511051 \\
\hline $\mathrm{O}_{3}$ & The high public interest in Batu Bara songketcloth & 0,0943 & 4 & 0,377069 \\
\hline $\mathrm{T}_{1}$ & The more expensive the raw materials & 0,11256 & 2 & 0,251297 \\
\hline $\mathrm{T}_{2}$ & Availability of human resources & 0,1633 & 3 & 0,489852 \\
\hline $\mathrm{T}_{3}$ & $\begin{array}{l}\text { Lack of time management in the process of } \\
\text { making songket cloth }\end{array}$ & 0,1207 & 2 & 0,241426 \\
\hline & \multicolumn{1}{|c|}{ Total } & $\mathbf{1 , 0 0}$ & & 3,173643 \\
\hline
\end{tabular}

Table 9. Ranking of Strategy Urgency

\begin{tabular}{|c|l|c|}
\hline No. & External Factors (sorted by value) & B*S \\
\hline $\mathrm{O}_{1}$ & There is government attention to the Batu Bara songket woven cloth & 1,302947 \\
\hline $\mathrm{O}_{2}$ & There are regular customers of Batu Bara songket cloth & 0,511051 \\
\hline $\mathrm{T} 2$ & Availability of human resources & 0,489852 \\
\hline $\mathrm{O} 3$ & The high public interest in Batu Bara songket cloth & 0,377069 \\
\hline $\mathrm{T} 1$ & The more expensive the raw materials & 0,251297 \\
\hline $\mathrm{T} 3$ & Lack of time management in the process of making songket cloth & 0,241426 \\
\hline & Total & 3,173643 \\
\hline
\end{tabular}

Based on the results of the IFAS matrix table and the EFAS matrix table above, it is known that the IFAS value is 3.305593 and the value of EFAS is 3.173643, so what stakeholder is number 1 , namely in a situation where the stakeholder experiences a period of growth. Thus it can be seen that the strategy that should be implemented is a growth strategy through Vertical Integration.

Based on the results of the IFAS Matrix Table and the EFAS Matrix Table above, it is known that the value of IFAS is 3.305593 and the value of EFAS is 3.173643 and is also 
based on the calculation of the number of strength values after being multiplied by a score greater than the total value of weakness after being multiplied by the score., which means that stakeholders have strength from an internal perspective. Likewise, the total opportunity value after being multiplied by the score value is greater than the total threat value after being multiplied by the score, which means that stakeholders have many opportunities. This means that stakeholders are in squared 1, which is a situation where stakeholders have strength from an internal perspective and also have strength in terms of opportunities. Therefore, stakeholders must make maximum use of their internal strengths and take advantage of existing opportunities. The right strategy is to use strength to take advantage of existing opportunities, namely with an aggressive strategy.

\section{Conclusion}

Based on the results and analysis of the previous chapter, the researcher can draw the following conclusions:

1. The business strategy of Muslim women who do UMKM Batubara songket cloth has been carried out well, by maintaining good quality and providing more motifs. On the other hand, the practitioners of Batubara songket cloth are expected to take advantage of technological advances, so that sales of coal songket cloth products can be marketed more widely

2. Stakeholders of the triple helix model in this study act as: a. Academics in this case are a source of knowledge with the latest theories and are relevant to the business developed by Batu Bara songket business actors run by Muslim women in Batu Bara to gain a competitive and sustainable advantage. b. Business is an entity that carries out business processes in creating added value and maintaining sustainable growth. c. The government acts as a regulator as well as a controller that has regulations and responsibilities in developing businesses. The government also has a role to coordinate stakeholders who contribute to the development of women's businesses in the treatment of Batu Bara songket cloth.

3. Based on the results of the SWOT analysis, it can be seen that the Stakeholders are implementing the SO (Strength and Opportunities) strategy, which is a strategy in which the company uses the strengths and opportunities it has to run its business. Muslim women business actors continue to maintain the quality and increase the number of songket motifs which are expected to increase public interest in the coal songket woven cloth and can meet the high interest of the community, especially for marketing abroad such as Malaysia, Brunei Darussalam, and Singapore so that they can benefit the Batubara songket cloth business actors. Muslim women business actors are encouraged to continue to maintain a comfortable work environment so that songket craftsmen can work comfortably to meet the high demand of the community, and with the many motifs of Batubara songket fabrics and a comfortable working environment will increase the number of customers for Batubara songket cloth, due to the many choices of motifs. and the increased performance of Batubara songket craftsmen. 


\section{References}

Abdul Halim Abu Syuqqah, Kebebasan Wanita, Jilid 2. Terj. Chairul Halim (Jakarta: Gema Insani Press, 1997).

Abdullah Abbas. Al-Ghazali Menjawab 100 Soal Keislaman Terj. Mi'atu Su'al An AlIslam(Ciputat: Lentera Hati, 2010).

Abdul Aziz dalam Buhan Bungin, Analisis Data Penelitian Kualitatif, Edisi Pertama Jakarta: PT. Raja Grafindo Persada, 2005).

Ahmad Nur Fuad. Hak Asasi Manusia dalam Perspektif Islam (Malang: LPSHAM Muhammadiyah Jawa Timur, 2010).

Al-Bukhari, Shahih Al-Bukhari Bab Dhahibah Al-Mar'ah, juz XVIII, h. 317, No hadis 5505. Muktabah Shamilah.

Al-Suyuti, Al-Jami'Al-Kabir, Juz 1, hal.8885, Maktabah Shamila APEC CEO Summit 2013 Indonesia. Kuliah Umum ABAC. 2013.

Barbara Freyer Stowasser. Reinterpretasi Gender: Wanita Dalam Al-Qur'an, Hadis Dan Tafsir.Cet. ke-1 (Bandung: Pustaka Hidayah, 2001).

Bin Raudha Arif Hanoeboen dan Pudjihardjo, Strategi Pengembangan Usaha Perempuan Pelaku UMKM di Kota Ambon.

Diah Tuhfat Yoshida, Arsitektur Strategi:Sebuah Solusi Meraih Kemenangan dalam Dunia yng Senantiasa Berubah (Jakarta: PT Elex Komputindo Kelompok Gramedia, 2004)

Freddy Rangkuti, Analisis SWOT Teknik Membedah Kasus Bisnis( Jakarta: Gramedia Pustaka Utama, 2015). 